\title{
Use of Bibliometrics in LIS Research
}

\author{
Mirza Muhammad Naseer \\ Librarian, Institute of Space Technology, Islamabad \\ mmnaseer@gmail.com \\ Professor Dr. Khalid Mahmood \\ Department of Library and Information Science, University of the Punjab, Lahore \\ khalid@dlis.pu.edu.pk
}

\begin{abstract}
Library and Information Science (LIS) literature mirrors the development of the LIS profession, which needs to be analyzed for growth of the profession and to overcome its weaknesses. Bibliometric methods have been widely used in LIS research for analysis of literature. This study aims to review use of bibliometrics in LIS research. It concludes that bibliometrics has been found to be very useful in solving diverse issues. However, its application to LIS literature is not very common in Pakistan and this area of research needs attention. It recommends provision of better access to literature, comprehensive bibliographical control and sharing of best practices to enhance the use of bibliometrics in LIS research.
\end{abstract}

Keywords

Bibliometrics; LIS research; Library and Information Science; Pakistan.

\section{Introduction}

The research process is imperative for the development of society and research results are valuable for the benefit of general public. Therefore, a central place is given to research in any development plan initiated in developed countries. This has resulted in scientific, social, political, economic and cultural development of the people. Research has been defined by Gay (1997) in these words: "Research is the formal, systematic application of the scientific method to the study of problems" (p. 20). Hernon (1999) is of the view that "In the social sciences, research is problem-centered and may not be aimed at developing cumulative theory. It might fulfill another function, such as description or evaluation” (p. 263).

Research is carried out for development of knowledge, improvement of existing knowledge, to provide solutions to specific problems, and to improve processes and practices. Since research findings have significance and value for society, research has attained an important place in all fields of knowledge. In the field of library and information science (LIS), research has played a crucial role in the creation and improvement of knowledge relating to the collection, organization, preservation and dissemination of 
information in different formats. This has resulted in the scientific, social, political, economic and cultural development of humankind.

Literature produced by LIS researchers is important for future development of the profession. It should be analyzed to observe prevailing trends in the profession but analysis cannot be done unless the literature is properly documented. Bibliographic control and analysis of research literature are time consuming and require concerted efforts on the part of researchers. Bibliometric analysis of existing literature acknowledges the efforts made by people and organizations involved in the research process. It also provides useful guidance for future research as it points out the areas which need future consideration.

\section{Objectives}

The objectives of this study are:

1. To review the use of bibliometric methods in LIS research.

2. To highlight bibliometric analyses conducted in Pakistan.

3. To recommend measures to improve LIS research by using bibliometric methods.

\section{Significance of the Study}

Professional development of a country in any field can be determined through literature produced in that field. This study, aimed at reviewing the use of bibliometric methods in LIS research, illustrates how bibliometric methods have been used in the library and information profession for analysis to solve different issues. This study also provides detailed review of bibliometric studies conducted in Pakistan. It will enable LIS researchers to develop an understanding of the present state of bibliometrics in Pakistan. It is the first review of bibliometric studies to originate from Pakistan. Recommendations of this study will provide guidelines for promotion of research in library and information science.

\section{Research Design}

This study is based on a literature survey. Existing literature has been utilized to review the use of bibliometrics in LIS research. Conclusions have been drawn on the basis of insight gained through the literature survey. Recommendations have been made on the basis of conclusions to improve the use of bibliometric methods.

\section{LIS Research}

Research is considered very significant for the development in LIS field like other fields of knowledge. It is the foundation for developing knowledge, improving existing knowledge, providing solutions to specific problems and for improving processes and practices. Library education and library practice are normally considered as two major areas of the profession, but Love (1980) proposed that research needs to be part of a total 
professional model to safeguard the profession and declares it as the third dimension of librarianship. Vickery (1971) believes that:

The library profession is a practical profession and a service profession, .... and it is important that research in this field should be seen to be making a positive contribution to the daily work of the profession as a whole, and not simply to be a sideline carried out for the benefit and amusement of researchers themselves. (p. 38)

\section{LIS Research in Pakistan}

LIS research in the geographic areas comprising Pakistan started as early as 1916 when Asa Don Dickinson wrote his Punjab Library Primer for library training classes at the University of the Punjab, Lahore (Kaser, 1992). This was the first textbook written outside the United States in the field of library science. Since then, this tradition has continued and Pakistani LIS professionals have been regularly contributing to library and information science literature.

Asghar (1992) reported on the status of LIS research in Pakistan by stating that "Library and information science research in Pakistan is still in its infancy despite the fact that six universities are imparting Master's degree programme containing a compulsory course on research methodology" (p. 158). Haider (1978) mentioned about 275 Master's theses submitted to the University of Karachi. Commenting on the nature of these theses he says that:

A large proportion of research at M.A. level is bibliographical, and certain major areas of interest have been overlooked. This was primarily because of the large number of students, of whom the majority did not show enough interest or lacked the necessary aptitude. (p. 333)

\section{Bibliometrics}

Bibliometrics has been defined as "the quantitative analysis of the characteristics, behaviour and productivity of all aspects of written communication, library staff and information users" (Mahapatra, 2000, p. 4). The word bibliometrics was introduced by Pritchard (1969) which substituted the earlier term "statistical bibliography" which was used for the same concept. Various techniques of bibliometric analysis help to determine special trends in literature of a given field of study. It is now popular among library professionals and researchers. Bibliometric studies are helpful in evaluating library services, collection development, policy refinement, decision making, resource allocation and even weeding. Data produced by bibliometric methods provides a scientific basis to library administrators for decision making. Bibliometrics has been considered useful for curriculum analysis (Juznic \& Urbanija, 2003) and for appraisal of research output quality (Middleton, 2005).

Two types of studies are included in bibliometrics: descriptive studies and evaluative studies. "Descriptive studies" are the productivity count achieved by counting the papers, 
books and other formats of communication while "evaluative studies" are the literature usage count made by counting the references/citations in research papers, books, and other formats of communication. Products of bibliometrics include prolific authors and institutions; ranking of journals, authors and institutions; compilations of the most cited journals, authors and papers; citation indexes; journal citation reports; and impact factor among others.

\section{Bibliometrics in LIS Research}

The use of bibliometric methods has become the norm in LIS research internationally for analysis and evaluation purposes. These methods have been used for comparison of international trends in LIS research. Uzun (2002) compared twenty-one core LIS journals published between 1980 and 1999 to ascertain the research contribution of developing countries and Eastern European countries. He found that the number of articles from China, Saudi Arabia, Turkey, Botswana, Ghana, Kuwait, and Taiwan has increased considerably while those in India, Nigeria, Pakistan, Brazil, and Poland have declined.

Rochester and Vakkari (1998) presented a comparative analysis of international LIS research. They compared national trends in the United Kingdom with those of Finland, Spain, Turkey, Australia and China. Comparison showed variation of emphasis and trends in research in countries under study. Information storage and retrieval emerged as the most popular subject in the international LIS literature whereas conceptual research and survey methods were most popular research methods.

A number of bibliometric studies have been conducted in developed countries like United States, the United Kingdom, Canada, Australia, and Denmark. Bibliometric studies are carried out in large number in the United States, but these are mostly conducted by research organizations not the academicians as is the case in Europe. It may be the major reason why less bibliometric studies are published from United States, or these are published in sources which are not reviewed. American companies like Thomson-ISI, SRI and CHI Research introduced innovations in bibliometric techniques. Bibliometric methods have been used for evaluation of research. For example, Hicks, Tomizawa, Saitoh and Kobayashi (2004) studied the use of bibliometric techniques of research evaluation by the United States Federal government. They reviewed various studies and concluded that bibliometrics is playing important role in research evaluation though traditionally peer review played more prominent role.

Buttlar (1999) used citation analysis to analyze sixty-one library science and information science dissertations and found that about 80 percent of citations were to single authors, and male authors are cited more frequently than female. The major subject area covered by these dissertations was public services. Results revealed that LIS researchers relied heavily (46 percent) on journal articles for their research. Citation analysis has also 
been used to evaluate the use of library collection. One such evaluation was done in the United States by Sylvia (1998) who analyzed the bibliographic citations of research papers by undergraduate and graduate students in the psychology department at St. Mary's University and made a decision for subscription or discontinuation of journals on the basis of their use and cost-effectiveness.

Zemon and Bahr (1998) examined articles published by college librarians in two journals during 1986-1996 and concluded that college librarians contributed less articles to the professional literature than their counterparts at universities. The study showed that college librarians wrote less about technology, systems related issues and cataloging. The number of articles contributed by both male and female authors was roughly equal. Library and information science research in Spain from 1977 to 1994 was reviewed by Cano (1999). The analysis revealed that the most popular area of interest in Spanish LIS literature was "L\&IS service activities", while empirical method was the most commonly used research method for producing the papers. Cano found that 68 percent of the articles were contributed by single authors. Kajberg (1996) conducted a content analysis of LIS serial literature published in Denmark to determine the subject focus during 1957-1986 while Hider and Pymm (2008) conducted content analysis to evaluate the distribution of empirical research methods described in high-profile LIS journals during 2005.

Bibliometric methods have also been used in LIS research in developing countries like Malaysia (Tiew, 2006; Tiew, Abrizah \& Kiran, 2002; Yazit \& Zainab, 2007), Ghana (Alemna, 1996, 2001; Fosu \& Alemna, 2002), South Africa (Ocholla \& Ocholla, 2007), China (Huanwen, 1996), Singapore (Ching \& Chennupati, 2002), Bangladesh (Khan, Ahmed, Munshi \& Akhter, 1998) and Botswana (Aina \& Mooko, 1999).

\section{Bibliometrics in LIS Research in Pakistan}

LIS literature was documented in Pakistan until 1990 by various researchers but there has not been comprehensive bibliographic control of the literature produced since then. Bibliometric studies of library literature are not common in Pakistan and this area of LIS research is now receiving the attention of researchers. Some studies have been conducted in the fields of medical science (Javed \& Shah, 2008; Ullah, 2006; Ullah, Butt \& Haroon, 2008), agriculture (Majid, 1995, 2000) and economics (Sharif \& Mahmood, 2004). However, only three bibliometric studies have been conducted in the LIS field. A review of these studies is presented in the following paragraphs.

The first bibliometric study of LIS literature in Pakistan was conducted by Mahmood (1996). He presented a statistical and subjective review of the status of library and information services in Pakistan by analyzing journal articles written on Pakistani librarianship in foreign journals. The study revealed that 92.47 percent of the articles were 
written by single authors and only 18.18 percent of authors contributed more than one article. The predominant language of 96.91 percent of the articles was English, while most popular subject area was "library and information science education and research.”

Another study was conducted by Khan and Samdani (1997) who analyzed the literature published in Pakistan Library Bulletin (PLB) during 1968-1997. Results of the study showed that middle-level professionals contributed the majority of the items. More than three fourths (77.27 percent) of the articles were descriptive whereas only 4.15 percent of the articles were based on empirical research. An overwhelming majority (90.90 percent) of contributors to $P L B$ were from Asia while 89.13 percent of the articles were from Pakistani authors. Male authors contributed 91.10 percent of the items and 75.69 percent of the items were in English. Major areas of interest for the authors of $P L B$, according to this study, were "academic libraries and librarianship" and "information technology". Most of the authors (46.51 percent) cited books in their articles whereas ALA Bulletin was the most cited journal.

A bibliometric study of LIS literature, presented by Anwar and Saeed (1999), quantitatively analyzed 251 items collected from LISA-PLUS which were contributed by sixty-four Pakistani library professionals. Results of this study indicate that only 7.6 percent of the items were the result of collaboration, and 7.8 percent of the authors were female. Anis Khurshid emerged as the most prolific author with twenty-two contributions. Journal literature, which represented 90.4 percent of the citations, was published in forty-three periodicals, mostly from the United States, while more than half of the journal literature was published in one national journal. The most productive period was 1987-89 and the least productive period was 1972-74. The most popular subject topic was "LIS education and manpower.”

Stressing the need to analyze the library and information science research in Pakistan, Asghar (1992) states that:

The acute inertia in the field of research and publication is attributable to a variety of factors. The professional bodies and the departments of library science in the country need to analyze the situation so as to remove the in-built flaws. (p. 158)

\section{Conclusion}

On the basis of the preceding review of literature and discussion, it may be concluded that bibliometric studies are very useful for LIS professionals for evaluating library services, collection development, policy making and refinement, decision making, resource allocation, analysis of curriculum and quality assessment of research output. These studies have the potential to determine the causes of problems faced by the LIS profession. 
Bibliometric methods have been effectively utilized to solve a variety of issues in LIS but this area of LIS research has failed to get attention of researchers in Pakistan. The LIS profession in Pakistan needs statistical data produced by bibliometric methods to solve issues hampering its growth. The situation of LIS research needs to be analyzed to explore trends and provide base for future research.

\section{Recommendations}

1. There is potential for improving LIS research by using bibliometric methods but access to recorded human communication, may be in print or online, is limited for researchers in developing countries. As the use of bibliometric methods requires wider access to the literature, it is recommended that publishers and online access providers should facilitate research by providing access to the relevant literature.

2. SAGE provides free access to its journals for limited periods. It is recommended that this example should be followed by other publishers. This will not only improve the use of bibliometric methods but also the overall research in developing countries.

3. Bibliographic data is the basis of bibliometric analysis and if there is limited bibliographical control or no control, it is not possible to conduct analysis. It is recommended that efforts should be made for the comprehensive bibliographical control especially in developing countries.

4. Best practices of LIS research in developed countries should be shared with other LIS professionals through publications and online communications so that the research culture may also flourish in those countries that pay less attention to the research.

5. Pakistani LIS researchers should consider the use of bibliometrics to analyze different issues being faced by LIS profession. It will help them generate useful statistical data about different aspects of the issues. This data will help them in solving these issues and provide a strong base for future research.

\section{References}

Aina, L. O., \& Mooko, N. P. (1999). Research and publication patterns in library and information science. Information Development, 15(2), 114-119.

Alemna, A. A. (1996). The periodical literature of library and information in Africa: 19901995. International Information \& Library Review, 28, 93-103.

Alemna, A. A. (2001). The periodical literature of library and information in Africa: 19962000. Information Development, 17(4), 257-261.

Anwar, M. A., \& Saeed, H. (1999). Pakistani librarians as authors: A bibliometric study of citations in LISA-PLUS. Asian Libraries, 8(2), 39-46. 
Asghar, M. (1992). Problems of library and information science research in Pakistan. In Sajjad ur Rehman, A. S. Chaudhry \& A. H. Qarshi (Eds.), Library education in Pakistan: Past, present and future (1st ed., pp. 151-161). Lahore: Punjab University Library Science Alumni Association.

Buttlar, L. (1999). Information sources in library and information science doctoral research. Library \& Information Science Research, 21(2), 227-245.

Cano, V. (1999). Bibliometric overview of library and information science research in Spain. Journal of the American Society for Information Science, 50(8), 675-680.

Ching, J. T. Y., \& Chennupati, K. R. (2002). Collection evaluation through citation analysis techniques: A case study of the Ministry of Education, Singapore. Library Review, 51(8), 398-405.

Fosu, V. K., \& Alemna, A. A. (2002). Fifty years of library literature on Ghana: A bibliometric study. Ghana Library Journal, 14, 1-5.

Gay, L. R. (1997). Educational research: Competencies for analysis and application (5th ed.). Islamabad: National Book Foundation.

Haider, S. J. (1978). Status of library research in Pakistan. Libri, 28(4), 326-337.

Hernon, P. (1999). Editorial: Research in library and information science - Reflections on the journal literature. The Journal of Academic Librarianship, 25(4), 263-266.

Hicks, D., Tomizawa, H., Saitoh, Y., \& Kobayashi, S. (2004). Bibliometric techniques in the evaluation of federally funded research in the United States. Research Evaluation, 13(2), 78-86.

Hider, P., \& Pymm, B. (2008). Empirical research methods reported in high-profile LIS journal literature. Library \& Information Science Research, 30, 108-114.

Huanwen, C. (1996). A bibliometric study of library and information research in China. Paper presented at the 62nd IFLA General Conference - August 25-31, 1996 Beijing.

Javed, M., \& Shah, S. S. (2008). Rawal Medical Journal - An analysis of citation pattern. Rawal Medical Journal, 33(2), 254-257. 
Juznic, P., \& Urbanija, J. (2003). Developing research skills in library and information science studies. Library Management, 24(6/7), 324-331.

Kajberg, L. (1996). A content analysis of library \& information science serial literature published in Denmark, 1957-1986. Library \& Information Science Research, 18, 2552.

Kaser, D. (1992). Asa Don Dickinson: A librarian of his times. In Sajjad ur Rehman, A. S. Chaudhry \& A. H. Qarshi (Eds.), Library education in Pakistan: Past, present and future (1st ed., pp. 3-10). Lahore: Punjab University Library Science Alumni Association.

Khan, M., \& Samdani, R. A. (1997). Library resources and publishing: 50 years analysis. Pakistan Library Bulletin, 28(4), 29-39.

Khan, M. S. I., Ahmed, S. M. Z., Munshi, N. U., \& Akhter, N. (1998). Library and information science literature in Bangladesh: A bibliometric study. Malaysian Journal of Library \& Information Science, 3(2), 11-34.

Love, E. (1980). Research: The third dimension of librarianship. Bulletin of Medical Library Association, 68(1), 1-5.

Mahapatra, G. (2000). Bibliometric studies on Indian library \& information science literature (1st ed.). New Delhi: Crest Publishing House.

Mahmood, K. (1996). Library and information services in Pakistan: A review of articles published in foreign journals. International Information \& Library Review, 28, 383405.

Majid, S. (1995). Trends in publishing agricultural research literature in Pakistan. Science \& Technology Libraries, 15(3), 55-75.

Majid, S. (2000). Bibliographical control of agricultural information resources in Muslim countries: A bibliometric analysis. Quarterly Bulletin of the International Association of Agricultural Information Specialists, 45(1-2), 13-20.

Middleton, A. (2005). An attempt to quantify the quality of student bibliographies. Performance Measurement and Metrics: The International Journal for Library and Information Services, 6(1), 7-18. 
Ocholla, D. N., \& Ocholla, L. (2007). Research in library and information science in South Africa: An analysis of journal research output from 1993-2006. Paper presented at the World Library and Information Congress: 73rd IFLA General Conference and Council, 19-23 August 2007.

Pritchard, A. (1969). Statistical bibliography or bibliometrics? Journal of Documentation, 25(4), 348-349.

Rochester, M., \& Vakkari, P. (1998). International LIS research: A comparison of national trends. Paper presented at the 63rd IFLA General Conference, August 31- September 5, 1997, Copenhagen.

Sharif, M. A., \& Mahmood, K. (2004). How economists cite literature: Citation analysis of two core Pakistani economic journals. Collection Building, 23(4), 172-176.

Sylvia, M. J. (1998). Citation analysis as an unobtrusive method for journal collection evaluation using psychology student research bibliographies. Collection Building, 17(1), 20-28.

Tiew, W. S. (2006). Authorship characteristics in Sekitar Perpustakaan 1994-2003: A bibliometric study. Malaysian Journal of Library \& Information Science, 11(1), 6575 .

Tiew, W. S., Abrizah, A., \& Kiran, K. (2002). Malaysian Journal of Library and Information Science 1996-2000: A bibliometric study. Malaysian Journal of Library \& Information Science, 6(2), 43-56.

Ullah, M. (2006). Impact of online resources on medical research: A citation analysis of Pakistani medical journals. Rawal Medical Journal, 31(2), 73-74.

Ullah, M., Butt, I. F., \& Haroon, M. (2008). The Journal of Ayub Medical College: A 10year bibliometric study. Health Information and Libraries Journal, 25, 116-124.

Uzun, A. (2002). Library and information science research in developing countries and Eastern European countries: A brief bibliometric perspective. The International Information \& Library Review, 34(1), 21-33.

Vickery, B. C. (1971). The administration of research in institutions. Paper presented at the Seminar on objectives and administration of library research, Nottingham, 20-21 September, 1971.

LIBRES ISSN 1058-6768 Volume 19, Issue 2, September 2009 
Yazit, N., \& Zainab, A. N. (2007). Publication productivity of Malaysian authors and institutions in LIS. Malaysian Journal of Library \& Information Science, 12(2), 3555.

Zemon, M., \& Bahr, A. H. (1998). An analysis of articles by college librarians. College \& Research Libraries, 59, 421-431. 